\title{
CONCENTRATION INDICES IN ANALYSIS OF COMPETITIVE ENVIRONMENT: CASE OF RUSSIAN BANKING SECTOR
}

\author{
Polina Stazhkova, ${ }^{1}$ Tatyana Kotcofana, ${ }^{2}$ Alexander Protasov ${ }^{3}$
}

\begin{abstract}
This article is devoted to the analysis and evaluation of competitive environments by using some indicators of market concentration. An analysis was made of the key (main) concentration indices most often used in countries with developed market economies. The state of the competitive environment in the banking sector of the Russian Federation is estimated with the use of indices. The consistency of these indicators to the basic antitrust regulations was investigated. The authors show that in order to obtain reliable results each of the available methods of monopoly power detection requires a detailed market analysis.
\end{abstract}

JEL Classification Numbers: D21, D43, G21, L13, L49; DOI: http://dx.doi.org/10.12955/cbup.v5.966

Keywords: concentration ratio, Linda Index, Herfindahl-Hirshman Index, market share, kernel

\section{Introduction}

The presence of monopolistic structures is one of the main problems while forming a competitive environment in a market economy. The challenge for antitrust authorities is to identify the monopoly and monitor its operations. This applies to firms that occupy a dominant position and abuse it. Traditionally, the most favorable condition for the emergence of a monopoly is a highly concentrated market.

The concentration of sellers reflects the relative sizes and number of firms operating in the industry. The concentration level will be the highest with the minimum number of firms on the market. It is also affected by the size of firms. The more firms differ in size, the higher the concentration level.

In turn, the level of concentration can determine the behavior of firms in the market. As a rule, the higher it is, the more firms will depend on each other or on the dominant firm. The monopolistic structure of the market is an exception. It is characterized by the maximum degree of concentration, but the only firm, the monopolist, does not depend on its actions from the behavior of competitors because of their absence. The market will have a lower degree of competition with a higher concentration level.

However, firms that occupy a dominant position, as a rule, do not recognize their position as monopolistic and they are trying to prove the absence of monopoly power. Thereby, there are clear criteria for determining the level of concentration. This makes it possible to assess the market structure, to establish the existence of a monopoly and to determine it quantitatively.

Economists have developed quite a lot of indices to measure concentration. Research by Khan et al. (2016) shows that the final assessment of the degree of competition and its impact on the effectiveness of economic policy depends on the choice of the concentration indices. In practice however, only the two most popular indicators are usually used. The Federal Antimonopoly Service of the Russian Federation in its analytical reviews and reports uses the concentration index - CR-3 and the Herfindahl-Hirschman index - HHI. In our view, it is necessary to expand the set of concentration indicators used to assess the competitive situation of the market more realistically.

\section{Data and methodology}

One of the first coefficients used by economists to analyze market structures was the market concentration index (CR). It shows the percentage of one or more large firms in the total volume of the analyzed market in terms of key economic parameters (sales volume, value added, money turnover, asset size, own and attracted capital, number of employees, etc.). Competition authorities are primarily interested in the firm's share in sales, so most often the concentration indicators, including CR, are calculated based on this parameter. Later, when analyzing concentration indices, we will speak specifically about market share as a proportion of income from sales of the company (or group of companies) in the total income from the sales of industry or market, implying that other parameters can be used.

\footnotetext{
${ }^{1}$ leading specialist, Department of educational programs, St. Petersburg State University. p.stazhkova@ spbu.ru

${ }^{2}$ Ph.D., assistant professor, St. Petersburg State University, t.kotsofana@ spbu.ru

${ }^{3}$ Ph.D., assistant professor, St. Petersburg State University, a.protasov@ spbu.ru
} 
US antitrust authorities have been actively using the concentration index to investigate market structures since 1968 (Gosudarstvo i rynochnyye struktury, 1993). This indicator is simple to calculate, that undoubtedly is its advantage. Usually this ratio is calculated for the largest companies in the market of a certain product. It gives an estimate the ratio of market shares of enterprises with the largest shares to the total market volume. The number of such large companies can vary. In the US (U.S. Department of Commerce, 2006) and France, the index is calculated for 4, 8, 20, 50 or 100 of the largest companies. In Germany, England, Canada, data on 3, 6, 10, etc. companies are considered. In Russia, this indicator has been calculated and published in official statistics since 1992 for three (CR-3), four (CR-4), six (CR-6) and eight (CR-8) of the largest sellers (Knyazeva, 2007). The formula for concentration index can be represented as follows:

$$
\mathrm{CR}_{\mathrm{n}}=\frac{\sum_{k=1}^{n} V_{k}}{\sum_{k=1}^{n} V_{k}+\sum_{j=n+1}^{N} V_{j}},
$$

where $\mathrm{CR}_{\mathrm{n}}$ is the concentration index of the given market, $V_{k}$ is the volume of sales for $k$-th large seller, $V_{j}$ is the volume of sales for $j$-th smaller seller, $n$ is the number of largest sellers in the market, $N$ is the total number of companies in the market.

The concentration index presents relative shares or percentage. The higher the values of this indicator are, the stronger the market power of the largest firms is, and the stronger the degree of concentration in the market is, the weaker the competition. Thus, for the same number of largest firms, the higher the degree of concentration, the less competitive is the industry.

As it was already mentioned above, this index can be calculated for a different number of major companies in the market of certain products. However, it is more appropriate to examine the values of this index for three or four large firms.

In Knyazeva (2007) the following criteria for comparing market structures are distinguished:

1. For three firms, the market is considered to be un-concentrated with an index below 45\%: CR$3<45 \%$;

2. The market is considered to moderately concentrated at the values of the index CR-3 between $45 \%$ and $70 \%$;

3. The market is highly concentrated when the index values are bigger than 70\%: CR-3> 70\%.

Despite the fact that the concentration index is fairly simple to use and interpret, it has a number of drawbacks. Firstly, it does not take into account the size of the firms, which were not included in the sample $k$. Secondly, it does not reflect the distribution of shares both within the group of the largest firms and beyond - between outsider firms. To solve this problem, the Lind index is actively used in the countries of the European Union. It allows identifying the largest firms on the market (Waterson, 1984), the so-called "oligopolistic core." Its calculation will be shown below. Thirdly, CR characterizes only the sum of shares of firms, but the gap between these firms can vary. There is a possible inaccuracy in its implementation due to this fact. It has some limitations in the application, since it does not allow differentiating the role of different producers in the market. This index can show the same numerical value for fundamentally different markets, distorting the true state of affairs. Consider two markets with a set of share distributions where one firm controls $80 \%$, the second - 5\%, the third $-3 \%$, the fourth $-2 \%$ and a set where the first firm occupies $24 \%$, the second $-23 \%$, the third - $22 \%$, the fourth - $21 \%$. Concentration will be measured as 0.9 for both markets, although it is obvious that in the first case the dominant position is occupied by one company and in the second case the distribution of the shares of the first four companies is more or less even (Pakhomova \& Richter, 2009). The use of the Herfindahl-Hirschman index makes it possible to overcome this drawback.

The concentration index is the simplest indicator of the presence or absence of a monopoly, but it is not precise enough, and moreover, has low information content. To address the above shortcomings, other indicators of market power can be used. We will look into those that are currently actively used in economically developed countries, and are the most successful in the facilitating antitrust policy. 
The Linda index was proposed by Remo Linda and is widely used in the European Union. Like the concentration index (CR), the Linda index is calculated only for a few of the largest firms, so it also does not take into account the situation on the periphery of the market. But unlike the concentration index, it is focused on accounting for the differences in the core of the market. The Linda index can show how many and what firms occupy dominant positions in the market. For this purpose, the index is calculated step by step. First for the two largest firms, then for three and so on, until the continuity of the function is violated (here, the tendency of the index decrease will be replaced by its increase). This violation of continuity shows that the latter company added to the calculation has a significantly smaller market share than any of the previous.

For the two largest firms the Linda index will be equal to the percentage of their market shares. According to Gosudarstvo i rynochnyye struktury (1993) we number the market shares of individual firms in a decreasing order, and then the Linda index for these firms will look as follows:

$$
\mathrm{IL}=\frac{k_{1}}{k_{2}} * 100 \%,
$$

Where IL is Linda Index, $k_{l}$ and $k_{2}$ are market shares.

Based on Gosudarstvo i rynochnyye struktury (1993) the Linda index for the three firms $k_{l}, k_{2}, k_{3}$ will be the arithmetic mean of the two ratios: the ratio of the share of the largest firm to the arithmetic average of the second and third largest firms; the ratio of the arithmetic average of the two largest firms to the share of the third largest firm.

$$
\mathrm{IL}=\frac{1}{2}\left[\left(\frac{k_{1}}{\left(k_{2}+k_{3}\right) / 2}\right)+\left(\frac{\left(k_{1}+k_{2}\right) / 2}{k_{3}}\right)\right] * 100 \% .
$$

The Linda index for the four firms $k_{1}, k_{2}, k_{3}$ will be the arithmetic mean of the three ratios: the ratio of the share of the largest firm to the arithmetic average of the other three largest firms; the ratio of the arithmetic average of the first two largest firms to the share of the other two largest firm; the ratio of the arithmetic average of the three largest firms to the share of the fourth largest firm.

$$
\mathrm{IL}=\frac{1}{3}\left[\left(\frac{k_{1}}{\left(k_{2}+k_{3}+k_{4}\right) / 3}\right)+\left(\frac{\left(k_{1}+k_{2}\right) / 2}{\left(k_{3}+k_{4}\right) / 2}\right)+\left(\frac{\left(k_{1}+k_{2}+k_{3}\right) / 3}{k_{4}}\right)\right] * 100 \% .
$$

In the same manner the Linda index for five, six and more firms can be calculated. If for two firms the index is 200 , for three is 170 , and for four is 230 , the continuity of the function is violated after adding the fourth firm. This means that the first three firms are the core of the market. Their market shares are significantly larger than the proportion of the fourth largest company and all the rest. If one or two firms occupy a clearly dominant position, the index will rise from the very beginning. In this case adding a third firm to the calculation increases the inequality of forces of the firms considered in the index.

The Linda index overcomes the above mentioned drawback of the concentration index. It is reflecting the distribution of market shares among the largest firms, and not just the ratio of the shares of the largest firms to all other sellers.

Another disadvantage of the market concentration index (CR) is the concealment of the true position in the market and the determination of the same numerical value for fundamentally different markets. To a certain extent it can be avoided while using the Herfindahl-Hirschman concentration index (HHI). The US Department officially refused CR, and adopted the HHI as the main characteristic of the market structure. Since June 1982, the HHI serves as the main reference point for the US antitrust policy in assessment of all kinds of mergers (Avdasheva \& Rosanova, 1998). This index can be used as a measure of concentration however, its main task is not to determine the market share controlled by several of the largest companies, but the characteristic of the distribution of "market power" among all the subjects of this market. Exactly this is the advantage of HHI over CR.

The firm's specific weight in the industry is used to calculate HHI. Just as for other concentration indicators, different parameters can serve as the basis for determining the specific weight, but the most important of them is the market share. It is assumed that the greater the share, the greater the potential for the emergence of a monopoly. In the calculation of this index all firms are ranked by weight from 
the largest to the smallest. Market shares of all producers of a certain product are needed to accurately calculate. It is not possible for a large number of firms.

The Herfindahl-Hirschman index is calculated as the sum of the squares of the shares of all firms operating in the market. It is the percentage of each firm present in the market in the total sales volume squared and sum while arranged in decreasing order:

$\mathrm{HHI}=\mathrm{Y}_{1}^{2}+\mathrm{Y}_{2}^{2}+\mathrm{Y}_{3}^{2}+\ldots+\mathrm{Y}_{n}^{2}$ or $\mathrm{HHI}=\sum_{i=1}^{n} Y_{i}^{2}, i=1,2,3, \ldots, n$,

Here $Y_{1}, Y_{2}, \ldots, Y_{n}$ are shares in decreasing order. Market shares can be expressed in fractions or as a percentage. In the first case, HHI will take values from 0 to 1 , in the second - from 0 to 10000.

According to international practice, the HHI value, close to zero, corresponds to the minimum concentration, HHI $<0,10$ (or HHI < 1000) - low level of concentration. In accordance with US law, the index value $0.10 \leq \mathrm{HHI} \leq 0.18$ (or $1000 \leq \mathrm{HHI} \leq 1800$ ) corresponds to the average concentration level, and HHI> 0.18 (or HHI> 1800) indicates a high level of market concentration (Knyazeva 2007). European legislation sets this limit at 0.2 (or 2000) (Guidelines, 2004).

It should be noted that this index reacts to a big number of firms as well as to the individual market share of each firm. It provides an opportunity to obtain information on the comparative capabilities of firms to influence the market situation in conditions of varying degrees of concentration. Petria et al. (2015) consider HHI to be the most correct of the concentration indices, since it takes into account the market shares of all firms and gives greater weight to firms with large market shares. However, the main advantage of the index is its ability to react quite sensitively to the redistribution of shares between firms operating in the market. Due to this sensitivity, it can indirectly indicate the magnitude of the economic profit obtained as a result of the exercise of monopoly power.

Table 1 compares the values of the concentration index (CR-3) with the indices of Linda (IL) and Herfindahl-Hirschman (HHI)

\begin{tabular}{|l|c|c|c|}
\hline \multicolumn{1}{|c|}{ Index } & \multicolumn{1}{c|}{ Concentration } \\
\cline { 2 - 4 } & low & \multicolumn{1}{c|}{ medium } & $70 \%-100 \%$ \\
\hline $\begin{array}{l}\text { Concentration Index } \\
\text { for three firms (CR-3) }\end{array}$ & $<45 \%$ & $45 \%-70 \%$ & $1800(2000)-10000$ \\
\hline $\begin{array}{l}\text { Herfindahl- } \\
\text { Hirschman Index } \\
\text { (HHI) }\end{array}$ & $<1000$ & $1000-1800(2000)$ & \\
\hline $\begin{array}{l}\text { Linda Index (IL) } \\
\text { The higher the market concentration, the earlier the continuity of the function is } \\
\text { violated (the decrease will be replaced by an increase). In case of domination of } \\
\text { one firm, the index will increase from the very beginning. }\end{array}$ & \\
\hline
\end{tabular}

As we could see, each of the concentration indicators examined has its advantages and disadvantages. The most adequate for reflection of the real market situation, in our opinion, is the HerfindahlHirschman index. However, with a large number of firms operating on the market, its calculation presents a certain complexity. The Linda index is also complex in calculation; it estimates the concentration only among the largest companies. Nevertheless, the use of IL helps to clarify the distribution of market power in the oligopolistic core.

The following criteria can be proposed to assess the merits of different concentration indices.

1. The concentration indices should give qualitatively consistent results both for the analysis of the market in general and for the analysis of the core of the market. For a less concentrated market this indicator should be less than for a more concentrated one, even if we do not calculate it for all sellers, but only for the largest ones.

2. The concentration index should increase with the increase in the share of a large firm by reducing the share of a smaller firm. 
3. The concentration index should decrease when a new firm enters the market, if its size is not larger than the size of the largest of the already existing firms.

4. The concentration index should increase when firms conduct $M \& A$ transactions.

From the indices considered, only the Herfindahl-Hirschman index meets all four criteria listed above. The Linda index and the CR only partially meet these conditions.

\section{Results and Discussion}

The concentration indices were calculated for analyzing the competitiveness of the Russian banking sector and six largest banks: Sberbank, VTB Bank Moskvy (together with VTB 24), Gazprombank, FK Otkrytiye, Rossel'khozbank and Al'fa-Bank. The key areas of banking activities are attracting deposits and lending to individuals and legal entities. The indices were calculated for each of these two areas, dividing each of them into two segments: services for individuals and for legal entities.

The market shares of these banks are shown in Table 2, the concentration indices (CR-3 and CR-6) and Herfindahl-Hirschman are presented in Table 3, and the dynamics of the Linda index is in Table 4.

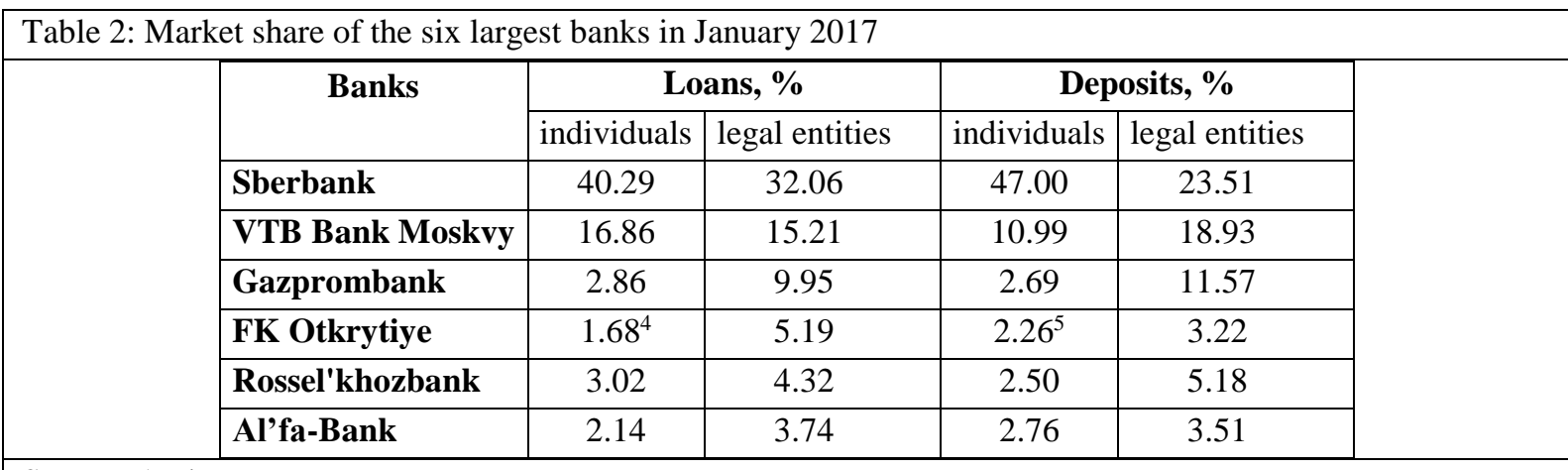

Source: Authors

Table 3: Concentration indices (CR-3 and CR-6) and Herfindahl-Hirschman Index for the six largest banks in January 2017

\begin{tabular}{|l|c|l|c|c|}
\hline \multirow{2}{*}{ Indices } & \multicolumn{3}{c|}{ Values } \\
\cline { 2 - 5 } & \multicolumn{2}{|c|}{ Loans } & \multicolumn{2}{c|}{ Deposits } \\
\cline { 2 - 5 } & individuals & legal entities & individuals & legal entities \\
\hline Concentration index (CR-3) & 60.17 & 57.22 & 60.76 & 54.02 \\
\hline Concentration index (CR-6) & 66.85 & 70.47 & 68.21 & 65.93 \\
\hline Herfindahl-Hirschman Index (HHI) & 1940.23 & 1437.22 & 2367.41 & 1117.20 \\
\hline
\end{tabular}

Source: Authors

Table 4: Linda Index for the six largest banks in January 2017

\begin{tabular}{|l|c|c|c|c|}
\hline \multirow{2}{*}{ Linda Index } & \multicolumn{3}{c|}{ Values } \\
\cline { 2 - 5 } & \multicolumn{2}{|c|}{ Loans } & \multicolumn{2}{c|}{ Deposits } \\
\cline { 2 - 5 } & individuals & legal entities & individuals & legal entities \\
\hline Two largest banks & 238.99 & 210.85 & 427.59 & 124.20 \\
\hline Three largest banks & 675.59 & 246.27 & 867.21 & 168.76 \\
\hline Four largest banks & 734.64 & 332.32 & 892.40 & 266.23 \\
\hline
\end{tabular}

Source: Authors

\footnotetext{
${ }^{4}$ The sixth biggest bank on the individuals' loans market is Raiffeisenbank

5 The sixth biggest bank on the market of individuals' deposits is Binbank
} 
CR-3 and CR-6 show that there is a medium level of concentration on all markets, while in services for individuals it is slightly higher. In loans for legal entities CR-3 is quite low but CR-6 is the highest. This can be explained by more equal distribution of shares among the three largest banks.

The Linda index is rising right from the start. Table 2 shows that Sberbank is the only dominating bank, for deposits for legal entities there are two dominant banks - Sberbank and VTB group. Not for all the markets IL will be the same. According to other indices the least concentrated is the segment of deposits for legal entities, it is also the lowest in IL.

HHI shows high concentration in deposits for individuals, moderately high (high by American standards) in loans for individuals and moderate in services for legal entities. The most competitive according to $\mathrm{HHI}$ is the segment of deposits for legal entities.

For the Russian bank system as a whole (600 banks) HHI in January 2017 was 1220. It indicates a moderate concentration. As Parsons \& Nguyen (2016) noted, in G7 countries the HHI for banks in the 2000-s was not lower than 5000, and after 2010 it is over 6000 .

The level of concentration in Russian banks is moderate according to other criteria. CR-5 in January 2017 was $59.04 \%$, but in 2008 it was $42 \%$, in 2010 - 48\% (Khandruyev \& Chumachenko, 2010). The HHI based on 957 banks in 2010 was 907 (Raksha, 2010). The growth rate is moderate. As a result, the concentration of the first five banks in Russia is comparable to European levels. As Leigh \& Triggs (2016) showed the market share of the four largest Australian banks is $94 \%$.

The Linda Index shows higher levels of concentration compared to the HHI, CR-3, CR-6. It is due to the fact that IL shows the concentration of the core, not the whole market. Due to the fact that in Russia most of the 600 banks have really small market shares, concentration levels look moderate. The six largest banks occupy less than $70 \%$. But there is clear dominant in the core of the market. The market share of Sberbank according to different estimates can be from $23 \%$ to $47 \%$. This can be seen only with the Linda index.

On the one hand, IL points out the leader and probable monopolist. On the other hand, it is unable to detect competitive forces presented by a number of smaller firms on the periphery.

\section{Conclusion}

These indices of concentration show the market structure with different levels of accuracy, they describe different aspects of the situation. In different circumstances, depending on the specific objectives of the antimonopoly policy, different concentration indicators may be most appropriate. However, in any case, detailed and multilateral analysis of the market is needed while using each of the considered indices, and possibly, their combination for a more realistic assessment. It is important not only to adequately assess the results obtained with the help of quantitative methods, but also to understand the reasons why the market has a high or low concentration. Without a meaningful analysis of the data used for calculating the concentration indices and their results, the approach to the implementation of the antimonopoly policy will be formal, one-sided, and, therefore, most likely, will not give the desired results.

\section{References}

Avdasheva, S.B., Rosanova, N.M. (1998) Teoriya organizatsii otraslevykh rynkov [Theory of organization of industrial markets]. Moscow.

Gosudarstvo i rynochnyye struktury [State and structures of the market] (1993) Economic school. Vol. 3. 205 - 224.

Guidelines on the assessment of horizontal mergers under the Council Regulation on the control of concentrations between undertakings. Official Journal of the European Union. 02.05.2004. C31/03 - 31/18.

Khan, H. H., Ahmad, R. B., \& Gee, C. S. (2016). Bank competition and monetary policy transmission through the bank lending channel: Evidence from ASEAN. International Review of Economics \& Finance, 44, 19-39. https://doi.org/10.1016/j.iref.2016.03.003. WOS:000378456800003

Khandruyev, A.A., Chumachenko, A.A. (2010) Konkurentsiya v bankovskoy otrasli: tendentsii, problemy, prognozy [Competition in the banking industry: trends, problems, forecasts] Bankovskoe Delo. № 11. 6-13.

Knyazeva, I.V. (2007) Antimonopol'naya politika v Rossii [Antimonopoly Policy in Russia]. Moscow: Omega-L Publisher Leigh, A., \& Triggs, A. (2016). Markets, Monopolies and Moguls: The Relationship between Inequality and Competition. Australian Economic Review, 49(4), 389-412. https://doi.org/10.1111/1467-8462.12185. WOS:000392658800001

Pakhomova, N.V., Richter, K.K. (2009) Ekonomika otraslevykh rynkov i politika gosudarstva [Industrial Economics and Sate Policy]. Moscow: Ekonomika. 
Parsons, R., \& Nguyen, J. (2016). Bank consolidation before and after the 2008 crisis. Applied Economics Letters, 24(2), 98101. https://doi.org/10.1080/13504851.2016.1164815. WOS:000387294700007

Petria, N., Capraru, B., \& Ihnatov, I. (2015). Determinants of Banks' Profitability: Evidence from EU 27 Banking Systems. Procedia Economics and Finance, 20, 518-524. https://doi.org/10.1016/S2212-5671(15)00104-5. WOS:000392265200065

Raksha, A.D. (2010) Konkurentsiya v bankovskoy sfere [Competition in the banking sector] Bankovskoe Delo. № 11. 22 -27. U.S. Department of Commerce. Economics and Statistics Administration (2006) Concentration Ratios: 2002. Lanham, Md.: Bernan.

Waterson, M. (1984) Economic theory of the industry. Cambridge University Press. 